\title{
Examining New Product Financial Performance Through Marketing Intelligence Quality, Customer Interaction Capabilities and Customer-Centric Commitment on Jordan's Micro Retail Fashions
}

\author{
Akif Yousef Al-Zyadat ${ }^{1} \&$ Ayed Al-Zyadat ${ }^{2}$ \\ ${ }^{1}$ Department of Marketing, College of Administrative and Financial Sciences, Irbid National University, Jordan \\ ${ }^{2}$ Department of Financial \& Banking Sciences, College of Administrative and Financial Sciences, Irbid National \\ University, Jordan
}

Correspondence: Ayed Al-Zyadat, Department of Financial \& Banking Sciences, College of Administrative and Financial Sciences, Irbid National University, Jordan.

Received: March 6, 2018 Accepted: April 3, 2018 Online Published: May 7, 2018

doi:10.5539/ijms.v10n2p95 URL: https://doi.org/10.5539/ijms.v10n2p95

\begin{abstract}
The purpose of this paper is to examine and test the mediator of customer interaction capabilities in relationship with quality market intelligence (MIQ) and customer centric commitment (CCC) with the new products performance (NPP). This paper chooses 184 micro retail fashions and examines the relationship of MIQ, CCC with CIC and NPP. The findings indicate that MIQ only affects the NPP, while the CCC is not. Nonetheless, CIC actually mediate the relationship between MIQ and CCC with NPP. By examining the diverse learning literature market, CRM, NPD and entrepreneurship, this paper offers a unique analysis on the quality of market intelligence and customer centric commitment and their impact on customer interaction capability and performance of new products. Conceptual and empirical discussion results to extend previous research on market orientation culture on SMEs.
\end{abstract}

Keywords: market intelligence quality, customer centric commitment, customer interaction capabilities, and new product performance

\section{Introduction}

The success of new product development is an essential part in the long-term development of company. Unfortunately, not all companies succeed in developing new products. A study by Cooper (1996) has shown that companies in the manufacturing industry that is capable of producing unique products and offer value to customer superiority are only able to achieve 79.6 percent success of the time. Even companies that use high-quality technology are only capable of achieving 43.2 percent successes (Cooper, 1996). This has led many researchers attention to the factors that can encourage new product development performance. Some researchers tried to approach their studies through market intelligence approach as the basis of the information search behavior of customers and competitors (Jaworski \& Kohli, 1993; Carbonell \& Escudero, 2010).

Market Intelligence continues to be a top priority for many organizations, and the role of market intelligence that is so dominant in improving business performance led to the concept to become an important foundation in the competition for many organizations and has consistently attracted many academics and practitioners to conduct research of this field (IKA, Jones et al., 2013). Some researchers have found that the intelligence market such as intelligence generation, intelligence dissemination and responsiveness to market are factors that really affect the performance of the company (Meunier-FitzHugha \& Lane, 2009; Carbonell \& Escudero, 2010; Chao \& Spillan, 2010; Haverila \& Ashill, 2011). This suggests that the market intelligence can drive business performance. Unfortunately, some dimensions of market intelligence developed by Jaworski \& Kohli (1993) and Carbonell \& Escudero (2010) do not always give positive impact on business performance or the performance of new products.

The two dimensions of market orientation, intelligence generation and intelligence dissemination, are proven not a strong incentive for new product performance. It is only responsiveness that gives positive effect on the performance of the new product development (Carbonell \& Escudero, 2010; Chao \& Spillan, 2010). Surprisingly, the findings by Rojas-Mendez \& Rod (2013) show that the business performance is influenced by market intelligence dissemination; but not with market intelligence generation and responsiveness. Moreover, other 
studies have shown that market sensing as part of the market intelligence is not a decisive factor of company performance, such as revenue, margin and profit growth rate (Morgan et al., 2009).

What is described above show that there are inconsistencies on research findings about the correlation of market intelligence to the performance of new products. Some researchers have included mediating variables that can bridge the correlation of market intelligence and new product performance, for example, the innovation speed (Carbonell \& Escudero, 2010), New product capability (Trainor \& Krush et al., 2013), Organizational knowledge (Toften \& Ottar Olsen, 2003). However, some studies which use the mediating variables of customer interaction capability to bridge market intelligence relationships with new product performance still seems have not been studied. Therefore, we use these variables to mediate the correlation of market intelligence with new product performance. We are of the view that the quality of information obtained from market intelligence activity is an essential resource for shaping customer interaction capabilities, and an increase in customer interactions which potentially improve the performance of new products. It is important to be tested, especially for micro-enterprises that have close relations with customers better than large companies (Zimmerer \& Scarborouggh, 1998). In a highly competitive market, such as the fashion industry, the quality of market information is needed to determine ways of micro entrepreneurs interact with customers effectively and efficiently.

Characteristics of micro enterprises are close to give customers the opportunity of testing the variable customer centric commitment as other antecedent of customer interaction capabilities and performance of new products. The previous research has proven that a customer centric or customer focus is antecedent of the company's performance. For example, customer responsiveness has effect on ROA (Pehrsson, 2013); Customer orientation has positive effects on individual service performance (Acer \& Zehir, 2013). There is an association of customer focus and new product performance (sanuri Mohd Mokhtar, 2013). However, several other studies have shown the opposite, customer centric has no positive impact on the firm performance. For example, Organizational customer orientation does not give a positive effect to the salesperson performance (Brashear et al., 2007); Customer Orientation does not affect the performance of the company (Aaron, Dibrell, \& Hansen, 2009). Therefore, it shows that the correlation of the customer centric and company performance is still filled with uncertainty. As in the study of the relation MIQ with NPP, we also assume that CIC also becomes mediation of CCC and NPP. We believe that companies that focus on the customer will have the capability of interacting with the customer. As a result, they will able to improve their performance, including the performance of new products. There is still unclear relationship between MIQ and CCC toward NPP. Therefore, it motivates us to propose testing on the mediating role of CIC as bridging process variables of such relationship because the purpose of this study is (1) to build a new approach to improve the NPP based on MIQ and CCC and (2) to test the mediation of CIC in relation of MIQ and CCC with NPP.

\section{Theoretical Background and Hypotheses Testing}

Conceptual Development of Customer Interaction Capabilities (CIC): Customer Interaction Capabilities (CIC) is a concept that we derive from the approach of Resource Based View (RBV) and Customer Relationship Management (CRM). According to Fahey et al. (2001), a company is formed by a variety of resources and capabilities possessed. Here, capabilities will describe a series of skills needed to use the resources. The resources here are the tangible and intangible entity that is available to companies that allow them to produce the efficiency and effectiveness of market offerings that have value for some marketing segments (Hunt, 1999). Information and relational sources are two of intangible resources that can drive superior business performance if used intelligently and diligently. The previous researchers like Jaworski \& Kohli (1993), Narver \& Slater (1990), and Vorhies et al. (2006) have agreed that the information and knowledge about customers and competitors obtained from market intelligence activity are valuable resource for improving business performance. These resources are the basis for increasing the capability of customer relationship management (CRM) of company because the relationship with the customer is only formed when the company has complete information about customers and competitors. Hair et al. (2010) explains that CRM is a business strategy designed to optimize profitability, revenue and customer satisfaction by focusing on the determination of the appropriate customer groups. The main focus of CRM lies in the use of information about the customer to create a marketing strategy in developing and maintaining long-term desirable customer relationships (Pride \& Ferrell, 2009). CRM has a basic philosophy that companies can increase profitability by building good relationships with their customers. As a result, customers become loyal and disloyal (Peppers \& Rogers, 2011; Weitz et al., 2012). Thus, the CRM is the process of cross-functional organization that focuses on building, maintaining, and improving long-term relationships with interested customers (Chen et al., 2010; Wang \& Feng, 2012). 
According to Chen et al. (2010) there are 5 of the most popular CRM activities today and each company needs to have the capability to apply it. These five activities are to share information, customer engagement, long-term partnership, joint problem solving, and technology based. Thus, CRM capability is defined as the ability or skill and knowledge accumulation companies use to acquire, deploy and utilize relational resources to achieve superior performance (Day, 1994; Morgan et al., Slotegraaf, 2009). One form of CRM capabilities is the ability to build a company's interactions with customers. The ability to interact with a strong customer is one of the most important marketing capabilities that can help companies achieve superior business performance and sustained competitive advantages (Day, 1994; Morgan et al., Slotegraaf, 2009). The above description shows the interaction between the customer and the company is the foundation of the CRM system. Because only through effective interaction, companies can learn about the expectations of customers, acquire and manage knowledge about them, negotiate a mutually satisfactory commitment, and build long-term relationships. Through effective customer interaction management, the company will obtain the customer data as a point of contact for satisfactory service. Here, touch points is the main base of contact with the customers, such as customer registration for certain services, customer communications about product information, handling warranty for the product, or customer talking to the seller and delivery personnel (Hair et al., 2010). According to Hair et al. (2010), a large amount of information can be obtained when the company establishes the organization of interaction with customers. Through interaction, the customer and the company can exchange information and develop a learning relationship. A customer typically defines interactions with the stated preferences. The company will respond by designing products and services around the desired customer experience.

Customer interaction process begins with gathering marketing information which will be the basis of CRM data. Based on this database, the company can apply the interaction with customers through campaign management, loyal customer retention programs, cross-selling other products and services, marketing communications plan, strengthening customer purchasing decisions, encouraging the sale of products to new customers, increasing the effectiveness of marketing and distribution channels to improve customer service (Hair et al., 2010). Therefore, customer interaction capabilities (CIC) are the central point in establishing good relationships with customers and increase the performance of the company in the long run. This study specifically highlights the capabilities of customer interaction, gives the ability to identify, acquire and retain profitable customers as an essential factor for improving the performance of new products of small and medium enterprises. Therefore, CIC is defined as the ability of the company to build an intensive interaction with the customer through the stages of customer identification, customer acquisition and retaining profitable customers.

Market Intelligence Quality (MIQ) and Customer Interaction Capability (CIC): The study of MIQ can refer to the views by Jaworski \& Kohli (1993) and Vorhies et al. (2006) on market-oriented business culture. According to Jaworski \& Kohli (1993), market intelligence is part of a market orientation. Market-oriented business culture is needed to boost the company's performance. Continual gathering information about the needs of customers and competitors' condition will help companies to identify what customers want. Enterprise knowledge about the customer needs to create superior customer value over time (Narver \& Slater, 1990; Garcia \& Calantone, 2002; Banterle et al., 2012). Here, Customer knowledge is the most common level of knowledge, more specialized and highly specialized (Tikkanen et al., 2011). Knowledge at the most general level can be knowledgeable about the industry, environmental and social trends. At a more specific level, the necessary knowledge is in the form of knowledge about customers in a particular market segment, which is typically behavior of customers in a particular market segment, as well as the distinctive needs and wants of customers in certain market segments. The most specific level of knowledge can be a knowledge of enterprise to customers individually or behavior of individual customers of other companies, their decision-making process, their wants and needs, as well as their contact information (Tikkanen et al., 2011).

According to Jaworski \& Kohli (1993), market intelligence is built by three-dimensional orientation of the market, namely intelligence generation, intelligence dissemination and responsiveness to market. Intelligence generation gathers information about market activities and competitive environment and interprets this information into the definition of objectives and strategies. Intelligence dissemination regards information dissemination activities throughout the functional areas of the company through horizontal communication to gain understanding or integration between different departments. Through intelligence dissemination, information is discussed and formally or informally distributed among the relevant users within organization (Moorman, 1995; Carbonell \& Escudero, 2010). Open sharing of information on all parties involved in the new product development process will improve better understanding of the capabilities and limitations of each party. However, some researchers have shown that high incoming information and engagement in an organization can have a negative effect on the pace of innovation (Moorman, 1995). 
Responsiveness to market is an evaluation to measure the effectiveness of measures aimed to meet the needs of customers, such as the determination of the target market, product offerings, distribution, and promotion (Jaworski \& Kohli 1993). Slater \& Narver (1995) have stated that the ability to gather information from customers and competitors will give advantages for company in response to the opportunities and threats. Thus, responsiveness to market is the enterprise perspective to external threats. In relation to this, responsiveness to market is seen as the ability to modify the organization's strategy to align environmental threats with opportunities. Responsiveness to market is one of the strategic factors that influence the competitive advantage (Hinsch et al., 2013). Responsiveness allows companies to reconfigure their processes to meet the needs of new markets, take advantage of information processing systems and adopt new products and processes to win the competition (Hinsch et al., 2013). Therefore, it is not surprising that the responsiveness to market is key in improving the success of the competition. Companies that are better to understand the needs and desires of customers will be able to respond to information about the needs and desires will generate more value from customers. Moreover, companies that are more active in gathering information about customers will be more responsive to customer needs and more aware of the movement of competitors (Hinsch et al., 2013).

In addition to the opinion by Jaworski \& Kohli (1993), Vorhies et al. (2006), state that the market intelligence capability is the ability of the company with its business resources to learn about the market and use knowledge of the market to improve the performance of the company. Market intelligence activity involves gathering information about customers and competitors, analyzing the market information, and utilizing it to develop marketing programs (Vorhies, 2006). Such information is vital in helping decision-making for strategic marketing organization oriented to market development. Thus, market intelligence capability is an organizational asset that facilitates the development of distinctive capabilities (Jordan et al., 1994). Therefore, the market intelligence quality is a quality of company in analyzing and distributing information to certain related parties and uses such information as aid in decision-making process of strategic marketing.

Market intelligence is the most important skills needed in the success of new product development. The important information, the accuracy and reliability of information on the changing needs and desires of today's customers or potential customers obtained from market intelligence will be a strong foothold in the new product development process. The information obtained from market intelligence also allows a reduction in the cost of the NPD, accelerate new product development time, and significantly contributes to the profitability of the company (Haverila \& Ashill, 2011). In general, many successful companies have utilized more in the collection and sharing of information, conducting market research, and involved in the acquisition of intelligence and learning (Garcia \& Calantone, 2002). In the process of new product development, information collection gives an opportunity to the new product development team to learn, so that, from the information obtained, they can act more quickly in decision-making (Carbonell \& Escudero, 2010).

Regarding that market intelligence is important part of market orientation (customers and competitors), it can be said that market intelligence can strengthen a company's CRM capabilities, and thus can improve the performance of the company. CRM capabilities include the ability to interact with customers such as the ability to identify the customer, get customers and retain profitable customers. Therefore, CIC is defined as the ability of the company to build an intensive interaction with the customer through the stages of identification, acquisition and retaining profitable customers. The quality of market intelligence will enable the company to develop the CIC. In new product development, market intelligence will determine the success of the quality of new products as the ability of interaction management with the customer is only possible when the company acquired more information about customers and competitors. Therefore, the following hypothesis is proposed:

$\mathrm{H}_{1}$ : Market intelligence quality (MIQ) has a positive correlation with the customer interaction capabilities (CIC).

Market Intelligence Quality (MIQ) and New Product Performance (NPP): According to Hart, Tzokas et al. (1999), the effective use of market information for the process of new product development (NPD) may improve the success rate of new products. Empirical evidence supports a positive relationship between the use of market information and new product performance (Byrne et al., 2007). A high level of utilization of information will increase the effectiveness of decision-making and implementation, which in turn will produce a new product performance to be greater (Moorman, 1995; Liu \& Tsai, 2013). Subsequently, Liu \& Tsai (2013) show that knowledge management capabilities and mechanisms to share information really affect the performance of new product development. Cooper \& Kleinschmidt (2000) and Moorman (1995) also show that the market intelligence generation has a positive influence on the performance of the new product. Luca \& Atuahene-Gima (2007) find a positive relationship between the acquisition of information and new product performance. While Kohli et al. (2000) have shown that there is a positive effect of market orientation on business performance, it means the market intelligence is really an important driver for improving the performance of the company (Chao \& Spillan, 
2010), including the performance of new products (Carbonell \& Escudero, 2010). In this study, the performance of new product is a measure of the success of new product development involving (1) the suitability of new products produced with the expected volume, (2) the ability to meet or exceed the sales receipt or expected results, (3) the ability meet or exceed the expected profit rate, (4) the ability to match or exceed the rate of expected return on investment (ROA), (5) the ability to match or exceed the expectations of the owner or management (Cooper, 1996; Byrne et al., 2007). Thus, the second hypothesis that we propose is:

$\mathrm{H}_{2}$ : Market intelligence quality (MIQ) has a positive correlation with the new products performance (NPP).

Customer Centric Commitment (CCC) and Customer Interaction Capabilities (CIC): According to Park et al. (2012), CRM implementation success depends on the strategy adopted, the people involved, the processes run and the technologies used. The involvement of people like the owners, managers, and employees become the most important factor for determining the successful implementation of the strategy, process and use of technology in CRM. Their commitment is needed to ensure that the company remains focused on the implementation of centric customer to always perform interactive communication with customers (Kaur \& Sharma, 2009; Park et al., 2012). Interactive communication can be done by determining the company policy that encourages customer interaction on a regular basis, face-to-face dialogue with customers, stimulate customers to provide information about changes to the terms of service, encourage customers to complain or give advice, encourage employees on the front lines to interact directly with customers and learn how to serve them better, and conduct regular surveys or interviews with customers to update information on customer service requirements (Kaur \& Sharma, 2009).

Commitment is an important factor in the success of marketing relationship as a determinant of corporate behavior, increase the efficiency and productivity of people in the company, especially employees (Morgan \& Hunt, 1994; Karagonlar et al., 2010; Bijvank et al., 2012; Li et al., 2014). Psychological literature has identified three types of organizational commitment, those are a commitment to sustainability, normative and affective (Irving et al., 2004; Meyer \& Allen, 2004; Kuo, 2013). Affective commitment considers the strength of the emotional attachment, identification and involvement of people with a particular organization. A Sustainable commitment considers the extent to which the commitment of people remains in the organization when they consider leaving the organization. Meanwhile, a normative commitment sees the feelings of the people on the remaining obligations in the organization (Anari, 2012; Wang et al., 2012; Joo \& Yoon et al., 2012). Among those commitments, affective commitment is regarded as one of the most important and beneficial because it can affect other components in the long term (Meyer \& Allen, 2004; Yoon et al., 2012). Employees with a strong affective commitment can continue the work with the organization and tend to make more effort to the organization (Yoon et al., 2012). Li et al. (2014), explains that a person who has affective commitment will be seen from their characteristics, such as a characteristic to: (1) consider the problems the company as a matter of him as well, (2) think that the company is very meaningful for himself, (3) discuss the company with others on something important, (4) have a strong affection on the company, and (5) feel part of the company. This is similar to the view of Sejjaaka and Kaawaase (2014) which state that organizational commitment is a tendency to remain in the organization and identify selves with the organization; involve in the organization of work roles; willingness to exert all efforts; and a desire to remain in the organization. Similarly, the opinion of the Crow, Lee et al. (2012), states that the organizational commitment is a psychological condition of an individual to an organization that is visible from the level of loyalty to the organization, the internalization of organizational goals, and dedication to the goals of the organization.

Customer-Centric Commitment is a synthesis of the concept of the commitment to the organization and customer centric. Thus, the customer-centric commitment is the strength of the emotional attachment, identification and involvement of people in the organization to implement the programs in satisfying the needs and desires of customers that ensure the achievement of the efficiency and effectiveness of marketing activities. Buhalis et al. (2007) describes a customer-centric management as an activity to capture and use customer insights to improve marketing effectiveness and serve them in the best way. Customer-centric management (CCM) is composed of a three-step process: (1) collecting and organizing information and data of individual customers; (2) using such information to be more effective in achieving the target fulfillment for existing customers; and (3) allowing customers to customize and personalize the service to meet their own needs and preferences. Thus, in order to achieve success in the implementation of the CCM, each person in the organization needs to have a strong commitment to implement the above three-step process. If follow the view of the Crow, Lee et al. (2012), Sejjaaka \& Kaawaase (2014), and Li et al. (2014), the quality of customer-centric commitment will be seen from the extent to which people in the organization, (1) have a tendency to remain in the organization and identify organizations to support programs that affect customer service and efficiencies; (2) directly involve in operational activities to increase customer satisfaction, (3) have a willingness to exert every effort in meeting the needs and desires of 
customers; (4) consider the problem of customer focus as their problem too, and (5) continue to discuss customer service issued with other people because it is very important and urgent.

Customer-centric is the orientation of the company with an emphasis on understanding the needs and desires of profitable customers to guarantee the efficiency and effectiveness of marketing activities (Kaur \& Sharma, 2009). Wang \& Feng (2012) describes a customer-centric organization system as an important determinant of CRM capabilities, including, customer interaction capabilities. Regarding that the implementation of customer-centric is depending on the people who play a role in the organization, the commitment of a strong customer-centric will enable the company to interact with customers. Therefore, the proposed third hypothesis is:

$\mathrm{H}_{3}$ : customer-centric Commitment positively affects customer interaction capabilities.

Customer-centric Commitment and new products performance: Previous studies have shown the correlation of loyalty to the organization with organizational outcomes such as absenteeism, tardiness, organizational performance, engagement, productivity, satisfaction, customer loyalty and turnover. These kinds of people do not just become a member of the organization, but more than that, they are willing to bend over backwards for the organization. People, who has a strong commitment will be able to contribute to the improvement of the performance of the organization because they regard the achievement of organizational goals is important. Conversely, people with low organizational commitment will have a low attention to the achievement of organizational goals and tend to hinder the improvement of organizational performance. The commitment of these people is important for companies to improve the competitiveness of the organization and maintain its market position (Suliman \& Kathairi, 2013). At the very least, a study by Kuo (2013) has demonstrated organizational commitment (sustainable, affective and normative commitment). People in the organization are key driver of organizational performance.

In customer-oriented company (customer-centric), the success of new products depends on the commitment of the stakeholders. Customer-centric management requires top management support and organizational commitment to CRM implementation. Top management support and organizational commitment are key factor for the success of CRM implementation in improving organizational performance (Chen \& Popovich, 2003). Previous studies also show that customer-oriented company is a company that is able to improve the company's performance, including the performance of new products (Appiah-Adu \& Singh, 1998; Zhang \& Duan, 2010; Pehrsson, 2013). It shows that customer-centric organizational commitment of the people involved in the organization will determine the performance of the organization, including the performance of new products in it. Thus, the fourth hypothesis we propose is as the following:

$\mathrm{H}_{4}$ : customer-centric Commitment positively affects the new products performance.

Customer Interaction Capabilities (CIC) and New Product Performance (NPP): Referring to the RBV approach presenting resource capabilities role in improving business performance and competitive advantage (Barney, 1991; Peteraf, 1993), the capabilities of the company in the field of CRM are also able to produce superior performance including performance of marketing and financial performance (Devinney et al., 2011). Wang \& Feng (2012) and Devinney et al. (2011) prove that there is a positive effect of CRM capabilities toward company performance. This study shows that companies that have a good CRM will be able to improve its performance. Considering that the customer interaction is the basis of CRM, the intensive customer interaction capabilities will become a key driver of new product performance enhancement. Gruner \& Homburg (2000) show that customer interaction during certain stages of new product development process has a positive impact on the success of new products. The collaboration with customers to provide information about the characteristics of customers is very useful for leaders in improving the success of new products. The ability to do good interaction with customers will enable the company to produce new products according to customer requirements. In the development of new products, the better the $\mathrm{CIC}$ is, the better the success of new products will be. Each new product entering the market must be introduced, promoted and brought closer intensively. Thus, the fifth hypothesis we propose is:

$\mathrm{H}_{5}$ : Customer interaction capabilities positively influence the performance of new products.

The influence of CIC on mediating the correlation of MIQ and CCC with NPP: This study thinks that the correlation of MIQ and CCC with NPP is likely to be mediated by the CIC. Market intelligence is the most important skills needed in the success of new product development. As we know, market intelligence (market intelligence generation, dissemination and responsiveness) has a positive effect on company performance (Jaworski \& Kohli, 1993), including the performance of new products (Moorman, 1995; Cooper \& Kleinschmidt, 2000; Carbonell \& Escudero, 2010). In the process of new product development, information collection gives an opportunity to the new product development team to learn, so that, from the information obtained, they can act more quickly in decision-making (Carbonell \& Escudero, 2010), including strategic decisions in the development 
of CRM (Wang \& Feng, 2012). Market intelligence can strengthen a company's CRM capabilities, including the ability to interact with customers. Therefore, the Quality of market intelligence will enable the company to develop the CIC.

Meanwhile, previous studies have shown that the customer-oriented company is a company that is able to improve the company's performance, including the performance of new products (Appiah-Adu \& Singh, 1998; Zhang \& Duan, 2010; Pehrsson, 2013). Therefore, the management of customer-centric requires support from stakeholders, especially top management and organizational commitment to CRM implementation. The commitment of stakeholders is needed to ensure that the company remains focused on the implementation of customer -centric with constantly do interactive communications with customers (Kaur \& Sharma, 2009; Park et al., 2012). Wang \& Feng (2012) describe the organizational system of customer-centric as determinants of CRM capabilities, including customer interaction capabilities. It shows that customer-centric commitment of those involved in the process of the organization will determine the performance of the organization, including the performance of new products in it. CIC is part of CRM capabilities, and these capabilities affect the performance of the company (DEVINNEY et al., 2011; Wang \& Feng, 2012). In other words, the better the CIC is, the better the company's performance improvement will be. This is consistent with the findings of Gruner \& Homburg (2000) about the existence of a positive effect of customer interaction during certain stages of new product development process to the success of new products. What is described above is basically suggests that CIC has the potential as a mediation of the correlation of MIQ and CCC with NPP. MIQ and CCC in addition to potentially increasing the NPP directly, also has the potential to improve the CIC. CIC here will strengthen the NPP. Thus the 6th and 7th hypothesis are as follows:

$\mathrm{H}_{6}$. CIC mediates the correlation of MIQ and NPP.

$\mathrm{H}_{7}$. CIC mediates the correlation of CCC with NPP.

\section{Research Design}

A structural equation model (SEM) is used to test the research model empirically by using data from the owner of the micro retail in Central Java, Indonesia. Confirmatory Factor Model is used to test the multidimensionality of a theoretical construct (construct validity test). In addition, SEMs are also used as a comprehensive test tool for full structural models. The analysis follows the process advocated by Black et al. (2010). First, we create a model of the path diagram causal relationship between the construct and its indicators. Second, we examine the un-dimensionality of each construct with confirmatory factor analysis. Third, we estimate the full equation of structural models for indicators that have passed the confirmatory test. Fourth, we discuss the convergence and discriminant validity before moving to the substantive analysis. SEM analysis is performed by using the Amos software version 22:00.

\section{Sample and Procedure}

Data are obtained from 187 complete questionnaires of 300 questionnaires distributed (62.33\%). We focus on the fashion industry because this industry shows that the level of innovation activity is higher than the creative industry in Indonesia (Department of Trade, Tourism and Creative Industries of Indonesia). Companies with employee ownership of less than 20 people are selected on the basis of criteria for small businesses in Indonesia with possession of less than 20 employees (CBS, 2014). A total of 300 retail fashions become the target population in this study. The questionnaire is accompanied by a signed covering letter submitted by officers who have been trained in advance to small business owners or to people who are entrusted with the small business. From the 300 questionnaires distributed, only 250 respondents give their consent to participate in this survey (83.33\%). The final evaluation of the questionnaires received show that there are 187 questionnaires $(62.33 \%)$ which is suitable to be used for data analysis. The selected respondents consist of $65 \%$ males and $35 \%$ females, most of them are married $(64.17 \%)$, not yet $(29.95 \%)$, and divorced (5.88\%). Furthermore, $52.41 \%$ of their education is high school or under, $29.95 \%$ and $17.65 \%$ are Diploma Bachelor's, and they have run a minimum of 2 years of retail fashion.

\subsection{Operational Variables}

1). QIA. Market intelligence quality is modified by the view of Kohli et al. (2000), which are essentially as quality market intelligence generation, intelligence dissemination market responsiveness and market intelligence gained from the activity of sensing market. From the three concepts, it is developed 5 item of questionnaire question regarding customer information quality, competitors' information quality, dissemination information quality, market sharing information quality, responsiveness and quality of market information.

2). CCC. Commitment customer centric is adopted from the initial view of Li et al. (2014), namely the ability of the company to build an intensive interaction with the customer through the stages of customer identification, 
customer acquisition and retaining profitable customers. 4 items questionnaire question are developed by regarding willingness to support customer service programs which are effective and efficient; exerting every effort in satisfying customer needs, customer focus and discussing customer service issues on a regular basis. 3). CIC. CIC concept is adopted from the initial view of Wang \& Feng (2012) which has been adjusted, i.e., the ability of the company to build an intensive interaction with the customer through the stages of customer identification, customer acquisition and retaining profitable customers. 4 item questionnaires are applied to measure the CIC, the ability to gain loyal customers, communicate with customers, serve customers and retain loyal customers. 4). NPP. NPP concept is adopted from the views of Cooper (1996) and Byrne et al. (2007) that have been adjusted; it is the description of the successful development of new products. 6 item questionnaires are applied to measure this construct; they are the compatibility with the expected volume, the result of expected sales, expected profit rate, the expected ROI, the owner's hope, and the contribution of new products in the company's development.

\section{Analysis}

We report the results of confirmatory factor analysis (CFA) for the full sample. We make observations on 19 indicators (5 indicators of QIA, 4 indicators of CCC, 4 indicators of CIC and 6 Indicators of NPP) to obtain 19 loading factor values $(\lambda 1-\lambda 19)$ to be relevant and in accordance with the existing provisions in AMOS. The loading factors for all latent variables are observed to have good validity if it has a value above 0.5 . Furthermore, we let all latent constructs correlated, so that the relationship between them can be evaluated. We report the results of testing Goodness-of-fit indices are good because it produces criteria in accordance with the recommended SEM (X 2165.218 , p-value is 0.132 , GFI is 0.905 , AGF is 0.876 , TLI is 0.837 and RMSEA is 0.027). Unless AGF and TLI indices are lower than recommended $(<0.90)$, the others are in conformity with the criteria recommended. X 2165.218 produce a p-value of 0.132 which is not significant at $\alpha 0.05$, GFI $>0.9$ and RMSEA less than 0.05 are the criteria recommended in the SEM. This shows that the recommended models are fit or have eligibility to examine the relationship between variables. To prove mediation of CIC, we use Sobel test.

Table 1. Descriptive, all 184. Inter-correlation, CR and AVE

\begin{tabular}{lllccc}
\hline \multirow{2}{*}{ Path } & \multirow{2}{*}{ CR } & \multicolumn{4}{l}{ Average Variance Extracted (AVE) in Bold } \\
& & CCC & MIQ & CIC & NPP \\
\hline CCC & 0.863 & 0.930 & & & \\
MIQ & 0.862 & 0.826 & 0.928 & & \\
CIC & 0.881 & 0.849 & 0.855 & 0.939 & \\
NPP & 0.652 & 0.793 & 0.906 & 0.872 & 0.958 \\
\hline
\end{tabular}

Note. CCC $=$ Customer Centric Commitment; MIQ = Market Intelligence Quality CIC $=$ Customer Interaction Capability; NPP $=$ New Product Performance.

Discriminant validity test: Construct reliability demonstrates high internal consistency, which means that the indicator has consistently represent the same latent constructs (Black et al. 2010). We use the construct reliability (CR) and the average variance extracted (AVE) to measure the internal consistency of indicators used. CR value is greater than 0.7 for the CCC, MIQ and CIC, as well as approaching 0.7 for the NPP. Moreover, the AVE value which is greater than the value of inter-correlation shows that each construct has good discriminant validity. We assess dimensionality through examination of the maximum likelihood estimates of the standardized estimates loading factor, which exceeds 0.5 or better than 0.6 (Black et al., 2010).

Table 2. Parameter estimates for the path: direct effects

\begin{tabular}{lllllll}
\hline & & & Estimate & SE & CR & P \\
\cline { 2 - 7 } $\mathrm{Miq}$ & $\rightarrow$ & CIC & 0.483 & 0.126 & 3.643 & $* * *$ \\
$\mathrm{CCC}$ & $\rightarrow$ & CIC & 0.450 & 0.116 & 3.527 & $* * *$ \\
$\mathrm{Miq}$ & $\rightarrow$ & NPP & 0.610 & 0.139 & 4.025 & $* * *$ \\
$\mathrm{CIC}$ & $\rightarrow$ & NPP & 0.377 & 0.142 & 2.543 & $0.011^{*}$ \\
$\mathrm{CCC}$ & $\rightarrow$ & NPP & -0.031 & 0.111 & -0.244 & 0.807 \\
\hline
\end{tabular}

Note. ${ }^{*} \mathrm{p}<0.05 ; * * * \mathrm{P}<0: 01$. 
Table 3. Parameter estimates for the path: indirect effects (Sobel test)

\begin{tabular}{|c|c|c|c|c|c|c|c|c|}
\hline Path & & & & & Beta & SE & CR & $\mathrm{P}$ \\
\hline Miq & $\rightarrow$ & CIC & $\rightarrow$ & NPP & 0.182 & 0.083 & 2.183 & 0.029 \\
\hline $\mathrm{CCC}$ & $\rightarrow$ & CIC & $\rightarrow$ & NPP & 0.170 & 0.077 & 2.183 & 0.028 \\
\hline
\end{tabular}

Note. ${ }^{*} \mathrm{p}<0.05 ; * * * \mathrm{P}<0: 01$.

The results show that there is a significant positive effect of the MIC and CIC $($ Beta $=0.483, \mathrm{t}-\mathrm{value}=3.643, \mathrm{p}$ $<0.01), \mathrm{CCC}$ on CIC $($ Beta $=0: 45, \mathrm{t}$-value $=3,527, \mathrm{p}<0.01)$, MIQ on NPP $($ Beta $=0.61, \mathrm{t}$-value $=4.025, \mathrm{p}<0.01)$ and CIC to NPP $($ Beta $=0.377, \mathrm{t}$-value $=2.543, \mathrm{p}<0.05)$. While CIC has no effect on NPP $($ Beta $=-0.031, \mathrm{t}$-value $=0.111, \mathrm{p}>0.05)$. This suggests the hypothesis H1, H2, H3, and H4 are supported, whereas H5 is not. This study aims to test whether CIC plays a mediating role in the correlation of MIQ and CIC with innovation. By regarding the $\mathrm{H} 6$ and H7, through the Sobel Test antecedents, it really affects NPP through CIC. More specifically, CIC acts as a full mediating role in the relationship between MIQ with NPP (indirect effects: Beta $=0.182$, $\mathrm{t}$-value $=2.183$, $\mathrm{p}<0.05$ ). In addition, CIC also mediates the relationship of CCC with NPP (indirect effects: Beta $=0.170, t-v a l u e$ $=2.183, \mathrm{p}<0.05)$. Therefore, the hypothesis $\mathrm{H} 6$ and $\mathrm{H} 7$ are supported.

\section{Discussion}

This study aims to investigate the correlation of MIQ and CCC with CIC and NPP, as well as the mediating role of CIC in relation with MIQ and CCC with NPP. This study has shown how important the role of CIC for companies engaged in the fashion industry with characteristics: short life cycle, unstable demand, low predictability and a high level of impulse purchases (Lowson et al., 2004). CIC has been a mediator in the relationship of MIQ and CCC with NPP. At least this study has given a new reference that gives a solution to the controversy over the relationship of market intelligence and customer centric with the performance of new products. Our results have confirmed the role of external and internal factors in strengthening CIC. External factors are derived from the quality of the information obtained from competitors and customers in the form of quality market information, while internal factors are derived from the commitment of the owners, leaders, and employees to focus on satisfying customers. As CIC external drivers, the quality of market information arises when a company has a strong market orientation culture. Meanwhile as internal CIC drivers, CCC appears in the form of a commitment to understand the needs of the company orientation and profitable customer that wish to guarantee the efficiency and effectiveness of marketing activities (Kaur \& Sharma, 2009).

We agree with the view of Narver \& Slater (1990), Garcia \& Calantone (2002) and Banterle et al. (2012) that the collection of market information continuously will help companies identify what customers want, and this knowledge will be a positive impact on firm performance. According Zimmerer \& Scarborouggh (1998), the secret of success in marketing is by knowing who the customers of the company, what they need, how much demand is and what his desire, before the competitors come to meet the needs, demands and desires. Customer knowledge abundant becomes an important resource to build the capability of interaction with customers. In another sense, the quality of market information will enable the company to interact with customers. Therefore, it is not surprising that the quality of market intelligence is an important driver for the creation of customer interaction capabilities and improved performance of new products. In fact, micro-enterprises are more effective than large companies in marketing relationships, which is the process of developing and maintaining long-term relationships with customers so that they can return to shop (Zimmerer \& Scarborouggh, 1998). Micro-enterprises can serve a narrow target market effectively and efficiently and achieve excellence in niche markets faced. Special advantages can include close relationships with customers, personal attention, focus on service, flexibility and management organizations and (Zimmerer, 1998). The main customer focus means involving the management of customer-centric to be more serious, so that, it continues to deliver superior value to customers. Given the implementation of customer-centric depending on the people who play a role in the organization, the strong customer-centric commitment will enable the company to interact with customers (Mugableh, 2017; Mugableh, 2017; Bekhet \& Mugableh, 2016; Mugableh, 2015; Mugableh, 2015; Mugableh, 2015; Bekhet \& Mugableh, 2013; Mugableh, 2013; Bekhet \& Mugableh, 2012).

Slightly different from the study of Wang \& Feng (2012) which shows the capabilities of CRM affect the performance of the company, this research is a dip in the CRM capabilities, the customer interaction capabilities, in relation to the performance of the company. Through effective customer interaction management, the company will obtain the customer data as a point of contact for service satisfying (Hair et al., 2010). The increase in customer interaction capabilities will impact the performance of the company (Day, 1994; Slotegraaf, 2009; Wang \& Feng, 2012). One thing that is different from other studies, we find that the CCC does not directly affect the 
performance of new products. This may occur when the willingness of stakeholders to support the programs of customer services effectively and efficiently; are directly involved in operational activities to increase customer satisfaction, willingness to exert every effort in satisfying customer needs, and a willingness to discuss customer service issues on a regular basis which are not sensitive enough to the performance of new products. In a highly dynamic fashion industry, each entrepreneur requires intensive interaction continuously to ensure customers keep abreast of the latest fashion. Without the interaction capabilities, it is very difficult for micro entrepreneurs to improve their business performance. Therefore, companies with a strong customer centric commitment and be able to boost the capabilities of the customer interaction is a company that has the potential of improving the performance of new products.

According to the analysis of the structural model as a whole, MIQ has a direct impact on the CIC and the performance of new products. While CCC only directly influences the CIC but it has no effect on the performance of new products. CCC does not directly affect the performance of new products through CIC. In particular, the quality of market intelligence contributes to customer interaction capabilities, which in turn improve the performance of new products. Consistent with research Wang \& Feng (2012), this study further confirms the mediating role of CIC in the relationship between the quality of market intelligence and business performance, which is neglected in the study of Toften \& Ottar Olsen (2003), Chao \& Spillan (2010), Haverila \& Ashill (2011), Krush et al. (2013), and sanuri Mohd Mokhtar (2013).

\section{Limitations and Future Research Recommendation}

Previous studies have put the capabilities of CRM as a mediating variable of customer orientation, customer centric organizational systems, and CRM technology with company performance. This study has been more specific by placing market intelligence as part of a market orientation, customer centric commitment as part of a customer centric organizational system, customer interaction capabilities as part of CRM capabilities, and new product performance as part of the company's performance. Meanwhile, in-depth study on other dimensions of research Wang \& Feng (2012) such as CRM technology, customer relationship upgrading capabilities and customer win-back capabilities in relation to the performance of the company still needs to be done. In the future, testing of other mediating variables of market intelligence and relationship of customer-centric commitment premises NPP upgrading capabilities such as customer relationship and customer win-back capabilities are excavated from the view of Wang \& Feng (2012), the pace of innovation (Carbonel, 2010), new product development capability (Trainor \& Krush), or organizational knowledge (Toften \& Olsen), is still needed in the development of the science of marketing management.

Previous studies have put the variable in the context of moderate internal market intelligence relationship with the performance of new products, such as the speed of innovation (Carbonel, 2010). By linking (Jaworski \& Kohli, 1993; Slater \& Narver, 1995; Greenley, 1995; Han et al., 1998), it argues that the external context variables, such as market and skills mortality, the intensity of competition and market growth, play a moderating role in the relationship between orientation market and business performance. Conclusions of previous studies are inconsistent. The external variables should add to our model, to test empirically whether the impact is managed. Additionally, Matsuno \& Mentzer (2000) argue that this type of business strategy will affect the impact of market orientation on business performance. Therefore, future studies should include the type of business strategy in our model to examine the relationship between the type of business strategy and existing construction.

\section{References}

Akgün, A. E., Byrne, J. C., Lynn, G. S., \& Keskin, H. (2007). New product development in turbulent environments: Impact of improvisation and unlearning on new product performance. Journal of $\begin{array}{llll}\text { Engineering } \quad \text { and } & \text { 24l(3), }\end{array}$ https://doi.org/10.1016/j.jengtecman.2007.05.008

Anari, N. N. (2012). Teachers: emotional intelligence, job satisfaction, and organizational commitment. Journal of Workplace Learning, 24(4), 256-269. https://doi.org/10.1108/13665621211223379

Appiah-Adu, K. S., \& Singh, S. (1998). Customer orientation and performance: a study of SMEs. Management Decision, 36(6), 385-394. https://doi.org/10.1108/00251749810223592

Aspara, J., Tikkanen, H., Pontiskoski, E., \& Jarvensivu, P. (2011). Exploration and exploitation across three resource classes Market/customer intelligence, brands/bonds and technologies/processes. European Journal of Marketing, 45(4), 596-630. https://doi.org/10.1108/03090561111111352

Bansal, H. S., Irving, P. G., \& Taylor, S. F. (2004). A Three-Component Model of Customer Commitment to Service Providers. Journal of the Academy of Marketing Science, 32(3), 234-250. 
https://doi.org/10.1177/0092070304263332

Barney, J. (1991). Firm Resources and Sustained Competitive Advantage. Journal of Management, 17(1), 99-120. https://doi.org/10.1177/014920639101700108

Bekhet, H. A., \& Mugableh, M. I. (2012). Investigating equilibrium relationships between macroeconomic variables and Malaysian stock market index through bounds tests approach. International Journal of Economics and Finance, 4(10), 69-81. http://dx.doi.org/10.5539/ijef.v4n10p69

Bekhet, H. A., \& Mugableh, M. I. (2013). Examining the equilibrium relationships between foreign direct investment inflows and employment in manufacturing and services sectors: evidence from Malaysia. Journal of Social and Development Sciences, 4(1), 32-38. Retrieved from https://www.researchgate.net/publication/253330028_Examining_the_Equilibrium_Relationships_between Foreign_Direct_Investment_Inflows_and_Employment_in_Manufacturing_and_Services_Sectors_Eviden ce_from_Malaysia

Bekhet, H. A., \& Mugableh, M. I. (2016). Blueprinting the equilibrium relationships between inward FDI and employment in the Malaysian economic sectors: time series models approach. Global Business and Economics Review, 18(2), 136-150. https://doi.org/10.1504/GBER.2016.075507

Bruce, B., Jordan, T., \& Wills, G. (1994). Realizing the Benefits of a Marketing Intelligentsia. Marketing Intelligence \& Planning, 12(6), 21-34. https://doi.org/10.1108/02634509410064196

Carbonell, P. A. I., \& Escudero, R. G. (2010). The effect of market orientation on innovation speed and new product performance. Journal of Business \& Industrial Marketing, 25(7), 501-513. https://doi.org/10.1108/08858621011077736

Chao, M. C. H., \& Spillan, J. E. (2010). The journey from market orientation to firm performance: A comparative study of US and Taiwanese SMEs. Management Research Review, 33(5), 472-483. https://doi.org/10.1108/01409171011041901

Chen, I. J., \& Popovich, K. (2003). Understanding customer relationship management (CRM): People, process and technology. Business Process Management Journal, 9(5), 672-688. https://doi.org/10.1108/14637150310496758

Chen, M. Y. C., Wang, Y. S., \& Sun, V. (2012). Intellectual capital and organizational commitment: Evidence from cultural creative industries in Taiwan. Personnel Review, 41(3), 321-339. https://doi.org/10.1108/00483481211212968

Christopher, M., Lowson, R., \& Peck, H. (2004). Creating agile supply chains in the fashion industry. International Journal of Retail \& Distribution Management, 32(8), 367-376. https://doi.org/10.1108/09590550410546188

Coltman, T. (2011). Customer relationship management and firm performance. Journal of Information Technology, 26, 205-219. https://doi.org/10.1057/jit.2010.39

Cooper, R. G. (1996). Overhauling the New Product Process. Industrial Marketing Management, 25(6), 465-482. https://doi.org/10.1016/S0019-8501(96)00062-4

Cooper, R. G., \& Kleinschmidt, E. J. (2000). New Product Performance: What Distinguishes the Star Products. Australian Journal of Management, 25(1). https://doi.org/10.1177/031289620002500104

Cross, M. E., Brashear, T. G., Rigdon, E., \& Bellenger, D. N. (2007). Customer orientation and salesperson $\begin{array}{llll}\text { performance. } \quad \text { European Journal of } & \text { Marketing, }\end{array}$ https://doi.org/10.1108/03090560710752410

Crow, M. S., Lee, C. B., \& Joo, J. J. (2012). Organizational justice and organizational commitment among South Korean police officers: An investigation of job satisfaction as a mediator. Policing: An International Journal of Police Strategies \& Management, 35(2), 402-423. https://doi.org/10.1108/13639511211230156

Day, G. S. (1994). The Capabilities of Market-Driven Organizations. Journal of Marketing, 58(4), 37-52. Retrieved from http://www.jstor.org/stable/1251915

Dong, X., Hinsch, C. A., Zou, S., \& Fu, H. (2013). The effect of market orientation dimensions on multinational SBU's strategic performance: An empirical study. International Marketing Review, 30(6), 591-616. https://doi.org/10.1108/IMR-12-2011-0284 
Eisenberger, R., Karagonlar, G., Stinglham, F., \& Stegier-Muller, M. (2010). Leader-member exchange and affective organizational commitment: the contribution of supervisor's organizational embodiment. Journal of Applied Psychology, 95(6), 1085-1103. https://doi.org/10.1037/a0020858

Fu, H., Yaoqi, L., \& Yanhong, D. (2014). Does employee-perceived reputation contribute to citizenship behavior? The mediating role of organizational commitment. International Journal of Contemporary Hospitality Management, 26(4), 593-609. https://doi.org/10.1108/IJCHM-02-2013-0082

Garcia, R., \& Calantone, R. (2002). A critical look at technological innovation typology and innovativeness terminology: a literature review. The Journal of Product Innovation Management, 19(2), 110-132. https://doi.org/10.1111/1540-5885.1920110

Gellynck, X., Banterle, A, Kuhne, B., Carraresi, L., \& Stranieri, S. (2012). Market orientation and marketing management of traditional food producers in the EU. British Food Journal, 114(4), 481-499. https://doi.org/10.1108/00070701211219513

Gruner, K. E., \& Homburg, C. (2000). Does Customer Interaction Enhance New Product Success?. Journal of Business Research, 49(1), 1-14. https://doi.org/10.1016/S0148-2963(99)00013-2

Hart, S., Tzokas, N., \& Saren, M. (1999). The effectiveness of market information in enhancing new product success rates. European Journal of Innovation Management, 2(1), 20-35. https://doi.org/10.1108/14601069910248856

Haverila, M., \& Ashill, N. (2011). Market intelligence and NPD success: a study of technology intensive companies in Finland. Marketing Intelligence \& Planning, 29(5), 556-576. https://doi.org/10.1108/02634501111153728

Hunt, S. D. (1999). The strategic imperative and sustainable competitive advantage: Public Policy Implications of Resource-Advantage Theory. Academy of Marketing Science Journal, 27(2), 144-159. https://doi.org/10.1177/0092070399272003

Isik, O., Jones, M. C., \& Sidorova, A. (2013). Business intelligence success: The roles of BI capabilities and decision environments. Information \& Management, 50(1), 13-23. https://doi.org/10.1016/j.im.2012.12.001

Jaworski, B. J., \& Kohli, A. K. (1993). Market Orientation: Antecedents and Consequences. Journal of Marketing, 57, 53-70. https://doi.org/10.2307/1251854

Jaworski, B., Kohli, A. K., \& Sahay, A. (2000). Market-driven versus driving markets. Journal of the Academy of Marketing Science, 28(1), 45-54. https://doi.org/10.1177/0092070300281005

Joo, B. K., Yoon, H. J., \& Jeung, C. W. (2012). The effects of core self-evaluations and transformational leadership on organizational commitment. Leadership \& Organization Development Journal, 33(6), 564-582. https://doi.org/10.1108/01437731211253028

Joseph, F., \& Hair, J. (2010). Multivariate Data Analysis (7th ed.). Upper Saddle: Prentice Hall.

Kaur, G., \& Sharma, R. D. (2009). Voyage of marketing thought from a barter system to a customer centric one. Marketing Intelligence \& Planning, 27(5), 567-614. https://doi.org/10.1108/02634500910977845

Kim, M., Park, J. E., Dubinsky, A. J., \& Chaiy, S. (2012). Frequency of CRM implementation activities: a customer-centric view. Journal of Services Marketing, 26(2), 83-93. https://doi.org/10.1108/08876041211215248

Kuo, Y. K. (2013). Organizational commitment in an intense competition environment. Industrial Management \& Data Systems, 113(1), 39-56. https://doi.org/10.1108/02635571311289656

Lamb et al. (2010). Marketing. Edisi 10 (South-Western Cengage Learning 5191 Natorp Boulevard Mason, OH 45040 USA).

Levy, M. et al. (2012). Retailing Management (8th ed.).

Lin, R. J., Chen, R. H., \& Chiu, K. K. H. (2010). Customer relationship management and innovation capability: an empirical study. Industrial Management \& Data Systems, 110(1), 111-133. https://doi.org/10.1108/02635571011008434

Liu, P. L., \& Tsai, C. H. (2013). Research on the Effects of Knowledge Management Capabilities and Knowledge Sharing Mechanisms on New Product Development Performance in Taiwan's High-tech Industries. Asian Journal on Quality, 8(2), 82-100. https://doi.org/10.1108/15982688200700016 
Lub, X., Bijvank, M. N., Bal, P. M., Blomme, R., \& Schalk, R. (2012). Different or alike?: Exploring the psychological contract and commitment of different generations of hospitality workers. International Journal of Contemporary Hospitality Management, 24(4), 553-573. https://doi.org/10.1108/09596111211226824

Luca, L. M. D., \& Atuahene-Gima, K. (2007). Market Knowledge Dimensions and Cross- Functional Collaboration: Examining the Different Routes to Product Innovation Performance. Journal of Marketing, 71(1), 95-112. https://doi.org/10.1509/jmkg.71.1.95

Meunier-Fitz Hugha, K. L., \& Lane, N. (2009). Collaboration between sales and marketing, market orientation and business performance in business-to-business organizations. Journal of Strategic Marketing, 17(3-4), 291-306. https://doi.org/10.1080/09652540903064860

Meyer, J. P., \& Allen, N. J. (2004). TCM Employee Commitment Survey Academic Users Guide 2004. Department of Psychology, the University of Western Ontario.

Moorman, C. (1995). Organizational Market Information Processes: Cultural Antecedents and New Product Outcomes. Journal of Marketing Research, 32(3), 318-335. Retrieved from http://www.jstor.org/stable/3151984

Morgan, N. A., Slotegraaf, R. J., \& Vorhies, D. W. (2009). Linking marketing capabilities with profit growth. International Journal of Research in Marketing, 26(4), 284-293. https://doi.org/10.1016/j.jiresmar.2009.06.005

Morgan, N. A., Vorhies, D. W., \& Schlegelmich, B. (2006). Resource-performance relationships in industrial export ventures: The role of resource inimitability and substitutability. Industrial Marketing Management, 35(5), 621-633. https://doi.org/10.1016/j.indmarman.2005.05.018

Morgan, R. M., \& Hunt, S. D. (1994). The Commitment-Trust Relationship Marketing. The Journal of Marketing, 58(3), 20-38. https://doi.org/10.2307/1252308

Mugableh, M. I. (2013). Analysing the $\mathrm{CO}_{2}$ emissions function in Malaysia: Autoregressive distributed lag approach. Procedia Economics and Finance, 5, 571-580. https://doi.org/10.1016/S2212-5671(13)00067-1

Mugableh, M. I. (2015). Economic growth, $\mathrm{CO}_{2}$ emissions, and financial development in Jordan: Equilibrium and dynamic causality analysis. International Journal of Economics and Finance, 7(7), 98-105. http://dx.doi.org/10.5539/ijef.v7n7p98

Mugableh, M. I. (2015). Equilibrium models of the Malaysian stock market and macro economy (1st ed.). Berlin: LAP LAMBERT Academic Publishing. Retrieved from https://www.researchgate.net/publication/283734717_Equilibrium_Models_of_the_Malaysian_Stock_Mark et_and_Macroeconomy

Mugableh, M. I. (2015). Time series analysis of inward foreign direct investment function in Malaysia. Procedia-Social and Behavioral Sciences, 172, 679-685. https://doi.org/10.1016/j.sbspro.2015.01.419

Mugableh, M. I. (2017). Estimating elasticity function of Jordanian aggregate import demand. Applied Economics and Finance, 4(2), 33-37. https://doi.org/10.11114/aef.v4i2.2085

Mugableh, M. I. (2017). World oil price volatility and stock returns fluctuations: evidence from Southeast Asian equity markets. Science International, 29(4), 759-762. Retrieved from https://www.researchgate.net/publication/318897616_WORLD_OIL_PRICE_VOLATILITY_AND_STOC K_RETURNS_FLUCTUATIONS_EVIDENCE_FROMM_SOUTHEAST_ASIAN_EQUITY_MARKETS

Narver, J. C., \& Slater, S. F. (1990). The Effect of a Market Orientation on Business Profitability. Journal of Marketing, 54(4), 20-35. https://doi.org/10.2307/1251757

Niininen, O., Buhalis, D., \& March, R. (2007). Customer empowerment in tourism through consumer centric marketing (CCM). Qualitative Market Research: An International Journal, 10(3), 265-281. https://doi.org/10.1108/13522750710754308

Pehrsson, A. (2014). Firms' customer responsiveness and performance: the moderating roles of dyadic competition and firm's age. Journal of Business \& Industrial Marketing, 29(1), 34-44. https://doi.org/10.1108/JBIM-01-2011-0004

Peppers, D., \& Rogers, M. (2011). Managing Customer Relationships: A Strategic Framework (2nd ed.) (Copyright C 2011 by Don Peppers and Martha Rogers. All rights reserved). 
Peteraf, M. A. (1993). The Cornerstones of Competitive Advantage: A Resource-Based View. Strategic Management Journal, 14(3), 179-191. https://doi.org/10.1002/smj.4250140303

Pride, W. M., \& Ferrell, O. C. (2009). Foundations of Marketing (3rd ed.).

Rojas-Me'ndez, J. I., \& Rod, M. (2013). Chilean wine producer market orientation: comparing MKTOR versus MARKOR. International Journal of Wine Business Research, 25(1), 27-49. https://doi.org/10.1108/17511061311317291

Sanuri Mohd Mokhtar, S. (2013). The effects of customer focus on new product performance. Business Strategy Series, 14(2/3), 67-71. https://doi.org/10.1108/17515631311325132

Sejjaaka, S. K., \& Kaawaase, T. K. (2014). Professionalism, rewards, job satisfaction and organizational commitment amongst accounting professionals in Uganda. Journal of Accounting in Emerging Economies, 4(2), 134-157. https://doi.org/10.1108/JAEE-01-2012-0003

Slater, S. F., \& Narver, J. C. (1995). Market orientation and the learning organization. Journal of Marketing, 59(3), 63-74. https://doi.org/10.2307/1252120

Suliman, A., \& Kathairi, M. A. (2012). Organizational justice, commitment and performance in developing countries: The case of the UAE. Employee Relations, 35(1), 98-115. https://doi.org/10.1108/01425451311279438

Toften, K., \& Ottar Olsen, S. (2003). Export market information use, organizational knowledge, and firm performance. International Marketing Review, 20(1), 95-110. https://doi.org/10.1108/02651330310462284

Trainor, K. J., Krush, M. T., \& Agnihotri. (2013). Effects of relational proclivity and marketing intelligence on new product development. Marketing Intelligence \& Planning, 31(7), 788-806. https://doi.org/10.1108/MIP-02-2013-0028

Wang, Y., \& Feng, H. (2012). Customer relationship management capabilities: Measurement, antecedents and consequences. Management Decision, 50(1), 115-129. https://doi.org/10.1108/00251741211194903

Zhang, J., \& Duan, Y. (2010). Empirical study on the impact of market orientation and innovation orientation on new product performance of Chinese manufacturers. Nankai Business Review International, 1(2), 214-231. https://doi.org/10.1108/20408741011052609

\section{Copyrights}

Copyright for this article is retained by the author(s), with first publication rights granted to the journal.

This is an open-access article distributed under the terms and conditions of the Creative Commons Attribution license (http://creativecommons.org/licenses/by/4.0/). 